AperTO - Archivio Istituzionale Open Access dell'Università di Torino

The Italian Economists as Legislators and Policymakers During the Fascist Regime

This is a pre print version of the following article:

Original Citation:

Availability:

This version is available http://hdl.handle.net/2318/1758060

since 2020-10-09T11:51:31Z

Publisher:

Palgrave Macmillan

Terms of use:

Open Access

Anyone can freely access the full text of works made available as "Open Access". Works made available under a Creative Commons license can be used according to the terms and conditions of said license. Use of all other works requires consent of the right holder (author or publisher) if not exempted from copyright protection by the applicable law. 


\title{
The Italian economists as legislators and policymakers during the fascist regime
}

\author{
Giovanni Pavanelli \\ Giulia Bianchi \\ University of Turin \\ University of Genoa
}

From the mid-nineteenth century until recently, Italian economists' work has been characterized by a close interaction between theoretical thinking and an insightful analysis of the most complex issues facing the economy and society and requiring adequate policy decisions. Thanks to a path breaking research, coordinated recently by M.M. Augello and M.E.L. Guidi, we know now quite a lot about the multifaceted work as legislators done by the economists in the Italian Parliament during the 'liberal age' (1861-1922) ${ }^{1}$. No overall analysis, however, was available of the same activity in the following years, in particular during the interwar period.

This paper, whose methodological approach draws on the above mentioned research, aims to analyse the role played by the Italian economists as members of the government and of the Parliament (the Chamber of deputies and the Senate) during the fascist regime. To this end, section one analyses the deep institutional changes that took place during this period, focusing in particular on the radical change in the balance of power between the executive and the legislative; section two provides an overview of the economists who played a significant role as legislators and policymakers under fascism; section three examines the work of the economists who became members of the government as ministers or undersecretaries (Alberto De' Stefani, Giacomo Acerbo, Arrigo Serpieri and Giuseppe Tassinari); the following sections analyse the legislative work of the economists who were, respectively, members of the Chamber of deputies and of the Senate.

1. The institutional framework: the changing role of Parliament and of government during fascism.

Recent literature (Melis, 2018; Soddu, 2008; Gentile, 2002; Fimiani, 2001) has highlighted the fact that during fascism there was a profound change in the functions exercised by the Parliament and the executive and

\footnotetext{
${ }^{1}$ Augello and Guidi, 2002; 2003. For a comparative analysis of the role of the economists in Parliament in several European countries in the years 1848-1920 cf. Augello and Guidi, 2005.
} 
indeed in the very nature of these institutions. From its very beginning, fascism rejected the principle of the "sovereignty of the people" as expressed through a freely elected, pluralistic Parliament and acted to shift the balance of power in favour of a government led by a charismatic $d u c e^{2}$. The degree of representativeness of the Chamber of deputies was then progressively reduced (the other Chamber, the Senate, was not elective: its members were appointed by the king and kept their office for life).

The process that led to the emptying of the functions of the elective chamber, however, was anything but linear: only in 1939, after many studies and analyses made by committees appointed by the regime, the Chamber of deputies was formally repealed and replaced by the "Chamber of Fasces and Corporations".

A first step in this direction was the Acerbo law ${ }^{3}$, approved in November 1923. This law attributed two thirds of the seats (356 on 535) to the list that had obtained the highest number of votes. The quorum was set at $25 \%$. As a consequence of this mechanism and of the climate of violence and intimidation established by the extreme right, the elections of April 1924 secured a large majority for the fascist and nationalist side. In November 1926 then, the residual voices of dissent were silenced by a measure that declared the deputies of the opposition no longer in office.

The final blow to the Chamber's representative functions was given by a new electoral law passed in May 1928 and further amended in January 1929. The new law, drawn up by Alfredo Rocco, at that time minister of justice and a leading figure of the nationalist movement, established a single national constituency and a single list, that included all the candidates (400 in total). The task of drawing up this list was attributed to the 'Grand Council of fascism', the highest constitutional body of the regime, on the basis of one thousand candidates chosen by the union confederations, various national associations, universities and academies (Salvemini, 1937; De Felice, 1968, 324-5).

This law, applied during the 1929 elections, transformed the elections into a plebiscite: voters were called upon to approve in full (or, in theory, to reject) the list elaborated by the regime. Indeed the appeal to voters, underlined Alfredo Rocco, did not take place in the name of an hypothetical "popular sovereignty" but to "test their state of mind, to improve the contact between the State and the masses" (quoted in Fimiani, 2001, 106). In other

\footnotetext{
2 The main objectives of Fascism from a constitutional point of view were, observes Fimiani, 2001, "the destruction of the pluralistic parliamentary system in its various articulations" and the establishment of the "absolute supremacy of the executive" (p. 95). On this point, it should be remembered that anti-parliamentarism was a widespread attitude in the nationalist literature since the beginning of the 20th century.

3 Giacomo Acerbo was at the time undersecretary to the presidency of the council of ministries and therefore a key advisor to Mussolini. Cf. infra, note 17.
} 
words, the regime did not at all consider itself bound to achieve popular legitimacy.

At the same time, the legislative function of the lower Chamber was substantially reduced: in the XXIX legislature (1934-39), for example, the vast majority of the bills passed were of government initiative (Melis, 2018, 307). The debate on the floor, in accordance with the anti-parliamentary rhetoric of the regime, was also compressed: particularly in the second half of the 1930s, several measures were approved without discussion.

Finally, as mentioned, in 1939 the Chamber of Deputies was replaced by a 'Chamber of Fasces and Corporations'. In this body the legislative function was exercised entirely inside the various committees: the draft laws were examined and, in general, approved without discussion and then transmitted to Mussolini and to the king for the final seal.

The evolution of the Senate is partly different: the senators were appointed by royal decree, maintained their function for life and came largely from the pre-fascist political élite, from the top of the judiciary and the army, or from academia. During the 1930s, however, also this Chamber was progressively "fascistized" (an active role was played by the "Fascist National Union of the Senate': cf. Gentile, 2002; Gentile and Campochiaro, 2003); from 1939, moreover, membership to the PNF became compulsory for newly appointed senators ${ }^{4}$. The dissent could be manifested through abstaining from taking part to the discussion on the floor (this was the position adopted by Luigi Einaudi).

Having said that, it appears reductive to see the Parliament under fascism as simple rubber stamp for the initiatives of the government (cf. Soddu, 2008; Melis, 2018). The Parliament was rather a "consultative body": deputies and senators cooperated to varying degrees in the final drafting of legislative measures with amendments, suggestions and recommendations.

Furthermore, it must be added that in several circumstances the debate in both Chambers reflected the views of different and sometimes conflicting interest groups inside the fascist regime (e.g. the landowners, the industrialists, the representatives of the fascist trade unions and of the professional associations). This happened in particular during the discussion of the annual budgets of the various ministries, which by law were submitted to the analysis of parliamentary committees and had then to be approved in the general assembly of both Chambers. In some cases, this offered the opportunity of real debate and even of criticism, albeit usually expressed with caution and masked by facade praise ${ }^{5}$. This point was

\footnotetext{
4 This obligation did not apply to the incumbent senators: Achille Loria and Luigi Einaudi, for example, never joined the fascist party.

${ }^{5}$ In several cases the ministries recognized openly that the topics raised during the debate were indeed relevant and promised to take note of them. Particularly in Senate the discussion became sometimes frank and direct. See in this regard a lively exchange of
} 
underlined also by an authoritative journal such as The Economist in a few correspondences from Italy, attributed to Luigi Einaudi ${ }^{6}$.

The role of the government also changed substantially: not surprisingly a clear centrality was assumed by the head of government (Mussolini). For many years the duce held also ad interim several key ministries, while the remaining ministries were entrusted mainly to experts in the respective fields, called to prepare legislative measures aimed at implementing key policy decisions inspired by the head of government.

\section{The role of the Italian economists as policymakers and legislators: an overview}

In this context, the Italian economists played a crucial role as builders of the 'new' fascist State but also, in a few cases, as bearers of critical views, to the extent that these could be still expressed ${ }^{7}$. Taking into consideration the period 1924-1943 (which includes four legislatures) several scholars of economics and statistics with academic status became members of the government or of Parliament: four of them (Alberto De' Stefani; Giacomo Acerbo; Arrigo Serpieri; Giuseppe Tassinari) played a key role in the government and, at the same time, were members of the Chamber of

views between the Senator Ugo Ancona and the Minister of Finance, Paolo Thaon di Revel during the discussion of the budget of the same ministry, in May 1935. Ancona: "The official total of public debts amounts to 105 billion. Now, in reality, the overall figure is much higher"; Thaon: "It is not true Senator Ancona. I have provided precise data to the Chamber"; Ancona. "Pardon, Honourable Minister. I have this habit, good or bad, of scrutinizing the relevant documents. Now if we sum up all the debts of the State, we reach at least 160 billion"; Thaon: "This is the estimate made by Salvemini abroad"; Ancona: "No, Minister, this is the bill made by the Financial Times, which reaches 160 billion and I believe that the figure is correct"; Thaon: "I rule out that the Financial Times can be better informed than the Italian Minister of Finance" (A.P. Senate, 28 th May 1935, 1327). Gaetano Salvemini (1873-1957), former professor of history at the University of Florence, was a leading antifascist in exile, very critical of Mussolini's regime. Cf. Salvemini, 1936.

${ }^{6} \mathrm{Cf}$. this passage, drawn from an article attributed to Einaudi, published on The Economist, 13th July, 1929, p. 70: "Budgets for the financial year from July 1, 1929, to June 30, 1930, have been unanimously approved by the Corporative Chamber of Deputies and by an overwhelming majority of the Senate. Notwithstanding, Parliament has not spared criticism of increases of expenditure and methods of accounting. The reports by deputy Mazzini to the Chamber and by senator Mayer to the Senate, on behalf of their respective Budget committees, are very interesting and it cannot be said that the two committees are less outspoken in their criticism than in the pre-war years" (Rpt. in Marchionatti, 2000, 475-6).

${ }^{7}$ For recent, insightful analyses of the main distinguishing features of the Italian economic thought in the interwar period, cf. Faucci, 2015; Barucci-Misiani-Mosca, 2017. 
deputies$^{8}$. Nine were members of the Chamber of deputies only: three of them (Antonio Graziadei; Arturo Labriola; Angelo Mauri) were anti-fascist and as such were stripped of office, as mentioned, in 1926; the remaining scholars (Agostino Lanzillo; Gaetano Zingali; Gino Arias; Vincenzo Ricchioni; Attilio Da Empoli and Zeno Vignati) were instead to various degree supporters of the regime.

During the same period, four authoritative economists were members of the Senate: Achille Loria; Luigi Einaudi; Pietro Sitta; Federico Flora.

Despite the diversity of their scientific and professional biography, it appears significant that several of the above mentioned authors and policymakers were applied economists. In particular, it is worth to underline the presence of a substantial group of agricultural economists (six in total, three of whom participated in government activities). This appears to confirm the centrality of agriculture for the regime both at an economic and social level (more than half of labour force was employed in agriculture). The presence of ideologists and/or theorists of corporatism is significant but, nevertheless, circumscribed.

\section{Building the behemoth: the economists at the government}

Analyzing the activity of the economists at the government during the fascist period, it is difficult to overestimate the role played by Alberto De' Stefani, minister of finance from November 1922 (and of treasury from December of the same year) till June 19259.

During his formative years De' Stefani was strongly influenced by Fedele Lampertico - an author whose methodological stance resembles that of the "German historical school" - but also by the leading representatives of economic liberalism such as Francesco Ferrara, Vilfredo Pareto and Maffeo Pantaleoni. From the very beginning, then, he was an eclectic thinker, who singled out as a key challenge facing the Italian economy the need to increase its productiveness: this had to be achieved through a valorization of the national resources and skills, the cooperation between workers and entrepreneurs and a more efficient and lean public administration.

\footnotetext{
${ }^{8}$ Arrigo Serpieri, after being part of this Chamber from 1924 till 1939, on that year was appointed member of the Senate.

9 De' Stefani (Verona, 1879-Roma, 1969) taught political economy at the Universities of Ferrara, Padua and Venice. On October 1925 he became dean of the newly founded Faculty of political science at the University of Rome. His writings include several essays on monetary theory, history of thought and demography. From 1926 till the end of the Thirties he was also the leading commentator on economic and financial matters for the Corriere della Sera, one of the most influential newspapers in Italy. Cf. Marcoaldi, 1986; 1991.
} 
After fighting as a voluntary during World War I, De' Stefani adhered to the fascist party and played an active role in the squads actions again the socialists. Elected in Parliament in 1921, he emerged in the early '20s as the most authoritative economist inside the fascist movement. In his writings and public discourses, he stressed the need to defend private initiative and middle class savings against excess taxation and inflation. Public expenditures should be severely checked; the government, however, should play a robust role in coordinating and promoting growth.

In 1922, on the eve of the "march to Rome", De' Stefani's views perfectly fitted Mussolinis's plans to appeal to the Italian conservative public opinion and the leading businessmen, by accreditating himself as a moderate leader, who favoured fiscal and monetary orthodoxy. Not surprisingly, when at the end of October Mussolini was asked by the king to form a new government, he selected the young De' Stefani as his Minister of finance.

Once in government, De' Stefani presented at the Chamber of deputies, on $25^{\text {th }}$ November $1922^{10}$, an ambitious programme aimed primarily at balancing the budget by eliminating the huge amount of deficit inherited from the war period and promoting investment and capital accumulation in the private sector (cf. Guarneri, 1953; Clough, 1964; Zamagni, 1991).

The first task was achieved by de' Stefani through substantial spending cuts (through a reduction of military expenditures and the dismissal of public sector's employees) and an increase in tax revenues, achieved primarily through a widening of the tax base - by including categories previously exempted such as skilled workers - and a reduction of tax evasion. In 1925 a progressive income tax was introduced. To foster saving and capital formation in the private sector, De' Stefani drastically reduced wartime taxation on corporate profits and abolished the rule that stocks had to be registered in the owner's name (De' Stefani, 1926).

Some fiscal measures adopted during this period clearly aimed at fostering the support of the middle class. Among them, a property tax reduction, the abrogation of the inheritance law and the liberalization of rents. With reference to customs policy, De' Stefani worked to restore multilateralism in trade and to keep customs duties at moderate levels (Clough, 1964, 224-5)

On the whole, fiscal consolidation was successful: speaking at the Chamber of deputies on May 30th 1923 and at Senate on December $8^{\text {th }}$ of the same year ${ }^{11}$, de' Stefani was able to announce that the task of balancing the budget had been nearly achieved. By far less effective, on the contrary, was

${ }^{10}$ Parliamentary Papers (hence A.P.), Chamber of Deputies (hence Chamber), 25 th November 1922, 8654-6.

11 A.P., Chamber, $30^{\text {th }}$ May 1923, 9508-11; Senate, $8^{\text {th }}$ Dec. 1923, 5744-53. 
his action on monetary and exchange rate stabilization. De' Stefani had to support Bank of Italy's bailout of the Banco di Roma and of other financial institutions which, mainly for political reasons, the fascist regime had decided not to let bankrupt. At the same time, he was unable to take concrete steps to consolidate the huge external debt accumulated during the war by Italy with its allies. Not surprisingly, the liquidity injected into the system to save the banks brought an increase of inflation, whilst adverse expectations fuelled a substantial devaluation of the lira.

De' Stefani reacted to this setback by adopting restrictionary measures on financial speculation, a policy which resulted in a serious stock market crash. In spite of a resolute defence of his policy at the Chamber of deputies on $2^{\text {nd }}$ June ${ }^{12}$, this brought in July 1925 to his dismissal as a minister of finance. From this date, the phase of economic liberalism was quickly abandoned and replaced by the adoption of protectionist measures and a strengthening of State intervention in the economy.

Starting from the mid-twenties, the regime strongly promoted also measures to foster agriculture, a crucial sector in terms of economic and social stability. The first, highly publicized initiative was the so called "battle for grain", launched in 1925 and aimed at reducing the balance of trade deficit and at ensuring national self sufficiency in the consumption of corn (Tattara, 1973; Daneo, 1980, 119-22). This objective should have been achieved mainly by means of productivity increases and was only partially successful. Even more ambitious was a vast program of land reclamation and improvement ("bonifica integrale") launched in December 1928 through the so called 'legge Mussolini'. This law set objectives that went far beyond the traditional works of drainage of swampy land and the fight against malaria, in that it aimed to substitute extensive with intensive cultivation and to promote colonization in vast areas of the country, including potentially one fifth of the national territory. In this context, the government was in charge of the fundamental works of drainage and land reclamation; instead the landowners were responsible for the works aimed at increasing the productivity of the land and fostering its colonization (irrigation canals, rural buildings, drinking water supply). The government in this case helped with subsidies which covered a part of the expense (Daneo, 1980, 130).

In spite of its denomination, the "Mussolini law" had been actually inspired by Arrigo Serpieri, by far the most gifted and authoritative agrarian economist in Italy at that time ${ }^{13}$. A leading expert in forestry and land

12 A.P., Chamber, 2nd June 1925, 4116-22.

13 Arrigo Serpieri (Bologna, 1877-Florence, 1960) taught agricultural economics at the Universities of Perugia, Milan and Florence. In 1925 he founded the National Institute of Agricultural Economics in Florence, which he presided until the second world war and in 1926 was appointed president of the "Accademia dei Georgofili". In 1939 became member of the Senate. After the fall of fascism Serpieri was temporarily deprived of his 
reclamation, Serpieri had been appointed in 1923 undersecretary of State for agriculture in the first Mussolini ministry, a post he held until 1924, when he was elected to the Chamber of deputies. In these years he drafted important legislative measures on the redemption of mountain areas and on land reclamation and improvement. In 1929 he was appointed undersecretary in charge of the implementation of the "bonifica integrale" 14 and worked with great energy, documented by five detailed annual reports drew up by himself and distributed among all members of Parliament.

Although the resources allocated by the government to the reclamation project were considerable, he wrote in his first report, these projects had to be selected with great care, according to a criterion of "maximum national utility" which included, in addition to economic utility, the supply of stable employment to a large number of temporary workers, rooting them permanently in a specific rural area (Serpieri, 1931, 194).

In Serpieri's intentions, therefore, the aim of the "bonifica integrale" was that of the transformation of large areas of Italian territory with the intention of establishing intensive production methods and promoting small or medium size farms. This would have helped in reducing the number of temporary agriculture workers, traditionally underemployed and prone to 'subversive' propaganda, transforming them into wealthy peasants and sharecroppers faithful to the regime.

To this end, however, it was crucial that the major reclamation works borne by the State were accompanied by works of improvement by the landowners. He therefore promoted a new law, approved in 193315, which attributed the responsibility for the reclamation work to ad hoc institutions, the consortia. These were bodies led, as a rule, by administrators elected by the landowners of the area but supervised and controlled by the ministry of agriculture. Among the preliminary tasks of the consortium there was that of elaborating a 'general plan of land reclamation' which included the public works required but also the plan of agrarian transformation to be realized by the landowners

The owners who were not able to carry out the works to which they were entitled, would have been expropriated and the property of their land transferred to private capitalists or to foundations (the most active during

professorship at the University. His academic writings focus on forestry, land reclamation and on the evolution of Italian agriculture. Cf. among others: Serpieri, 1930; 1935; 1957. On Serpieri's life and work cf. Dini, 2010; Misiani, 2018. For an overview of academic research on agricultural economics in interwar Italy cf. Zaganella, 2015.

14 This happened in the framework of a significant organizational change inside the executive: the ministry of national economy, which had been deprived of most non agricultural competences in favour of the ministry of corporations, was renamed ministry of agriculture and forestry and entrusted, as we will see later, to Giacomo Acerbo.

15 "Testo unico sulla bonifica integrale", 13th February 1933, no. 215. 
these years was the "Opera nazionale combattenti" that carried out the colonization of the Agro Pontino).

Serpieri recognized that expropriation was an extreme sanction ${ }^{16}$; indeed the ongoing economic crisis had aggravated the position of many owners, who did not have sufficient financial means to complete the work for which they were responsible. A possible solution, in his view, should have been for them to sell part of their land and improve with the proceeds the productivity of the remainig part of the property.

On these aspects, as we will see, a strong contrast with the class of owners would soon have been triggered in Parliament ${ }^{17}$.

It is worth remembering that Serpieri could hardly have carried out his reform projects without the support of Giacomo Acerbo, who had been appointed minister of agriculture and forestry in September 1929. This ministry, by the way, had been constituted on that occasion, unifying the control of agricultural issues managed since 1923 by the ministry of national economy ${ }^{18}$ : a measure interpreted by many observers as a further sign of the crucial role attributed to the agricultural sector by the regime.

A leading member of the fascist party and a close collaborator of Mussolini who, as already mentioned, had entrusted him with the drafting of the electoral law of 1923, Acerbo was also an authoritative agrarian economist ${ }^{19}$. Called to join the government in 1929, he had supported Serpieri's appointment as undersecretary and shared his vision on the subject of land reclamation.

16 In his opinion, however, this measure was justified in the case of owners who were "stubbornly failing to fulfil the duties that the fascist State attributes to property as a social function" (Serpieri, 1933, 80).

17 In a speech held at the Senate in 1933 Francesco Rota, a landowner and silk entrepreneur of northeast Italy, openly criticized Serpieri's approach: "Fascism guarantees the right of ownership that is, despite all the declining bolshevism, the cornerstone of our civilization. These doctrinal statements of large, indeterminate expropriations are dangerous" (A.P., Senate, 21th March 1933, 5933).

18 In the previous years the ministry of national economy had been deprived of most of its non agricultural competences in favour of the ministry of corporations and was therefore suppressed.

19 Giacomo Acerbo (Loreto Aprutino, 1888 - Rome, 1969) graduated in agronomy at the University of Pisa in 1912. In the postwar period he started an academic career as assistant professor in political economy at the University of Rome and at he same time took part to political activity as an active member of the fascist party. Elected at the Chamber of deputies in 1921, he became a close collaborator of Mussolini. In the meantime he carried on academic work in agricultural economics and in 1928 became professor on that discipline at the High school of commerce, later Faculty of economics, University of Rome. Minister of Agriculture and forestry till January 1935, on that year was appointed president of the International Institute of Agriculture in Rome. Member of the Great fascist council, in July 1943 voted against Mussolini. Cf. Parisella, 1988. 
As soon as he took office in his ministry, however, the biggest challenge he had to face was the collapse of the prices of the agricultural products and of farm incomes as a consequence of the world depression. His report on the budget of his ministry, held in the Chamber of deputies in April 1930, for example, is dominated by the theme of the sharp reduction in the prices of basic agricultural goods such as wheat, wine, livestock products. While not denying the seriousness of the problem, Acerbo expressed at that time the confidence that the crisis was temporary, bound to be solved through a decrease of stocks and a reduction in nominal wages ${ }^{20}$.

The following three years were characterized by the persistence and even worsening of the economic depression. The parliamentary papers in this period document several severe complains - albeit usually tempered by declarations of allegiance to the regime -and pressing requests of help by the representatives of the farmers and landowners, presented during the discussion of the annual budgets of the ministry ${ }^{21}$.

In two encompassing speeches given respectively in the Chamber of deputies and the Senate, respectively in February and March 193322, Acerbo recognized the gravity of the crisis while claiming the validity of the criteria adopted by the government "to defend and strenghten" the sector. The most serious problem, he agreed, was the collapse of the prices of most agricultural products, which in turn had led many farmers to face a "reduction in agricultural revenues below production costs". The situation appeared to be particularly serious with regard to livestock farming and silk and wine production. The government, maintained this time Acerbo, had not waited for "the slow unfolding of market rebalancing forces" to bring back equilibrium ${ }^{23}$. On the contrary, it had defended national producers by preventing, through import duties and other measures, domestic prices from falling at the international level. It also promoted the improvement of production techniques and the increase in the use of chemical fertilizers.

Another key problem, partially connected with the previous one, was that of indebtedness. The total debt of Italian agriculture, Acerbo estimated, amounted to 9-10 billion lira, out of a total value of production of about 2530 billion. This sum, although not excessively high at an aggregate level, was strongly concentrated in some regions: in particular, Emilia, Lazio, Veneto. In this case the government had intervened by granting aid to 'meritorious'

\footnotetext{
${ }^{20}$ A.P. Senate, $9^{\text {th }}$ April 1930, 2346-49.

${ }^{21}$ Complains focused on the collapse of the prices of the main agricultural goods but also on the high tax burden and the high interest rates on loans to farmers. Cf. A.P., Chamber, 21th February 1933, 7672-7705; A.P., Senate, 21th March 1933, 5926-52.

${ }^{22}$ A.P., Chamber, 24th February 1933, 7804-18; A.P., Senate, 24th March 1933, 6001-16.

${ }^{23}$ A.P., Chamber, 24th February 1933, 7805.
} 
farmers: abandoning them to ruin would have been a "serious political error as well as an economic one"24

In his speech held at the Senate, Acerbo strongly defended the project of "integral reclamation" coordinated by Serpieri. In three years it has allowed to carry out reclamation works for an amount of 1600 million and to ensure employment to tens of thousands of workers. The execution of the works by the State had to be followed now by those due by the private sector: if a few of them were unable to do so due to lack of capital, they would have had to voluntarily give up part of their property to those who had that will, before they were forced to do $\mathrm{so}^{25}$.

On this point, however, a tough contrast soon arised between the representatives of the landowners in Parliament and the ministry of agriculture. Until 1933-34, the norms on the obligations of the landowners had remained a dead letter. In December 1934, however, Serpieri presented in Parliament a draft law to make these norms effective. This new law, maintained Serpieri and Acerbo intervening at the Chamber, did not intend to violate the right of property; it simply reaffirmed the social duties of the owners towards the nation ${ }^{26}$. After an extensive debate, the proposal was indeed approved by the Chamber of deputies but was then put into a standstill, as a consequence of the fierce opposition by the landowners.

This setback, almost unprecedented during the regime, led, in January 1935, to the resignation of Acerbo and Serpieri. They were replaced respectively by Edmondo Rossoni - an ambitious leader of the fascist trade unionism who, however, possessed hardly any notion of agronomy 27 - as a new minister of agriculture, and by Gabriele Canelli, a lawyer from Apulia who enjoyed the trust of the landowners, as undersecretary for land reclamation.

Canelli maintained this position until his death in April 1937. It is not surprising that, for at least two years, the land reclamation initiatives were radically scaled down. In the same period, probably as a consequence of an implicit deal between the landowners and Mussolini himself (Daneo, 1980, 132-3) most of the resources previously invested in agriculture were anyway diverted by the regime to finance the war in Ethiopia and the rearmament process.

\footnotetext{
24 Ibidem, 7813-16.

25 A.P., Senate, 24th March 1933, 6013-15.

${ }^{26}$ A.P. Chamber, $12^{\text {th }}$ Dec. 1934, 494-507.

27 For a tranchant judgement of Rossoni's work at the ministry cf. the Diaries of Giuseppe Tassinari, at that time undersecretary of agriculture. In this text, recently published, Tassinari judged Rossoni "an incompetent and slacker minister, concerned exclusively with his own interests" (Tassinari, 2019, 68).
} 
To partially compensate this standstill to agricultural policy, in January 1935, Giuseppe Tassinari ${ }^{28}$ a first rate agricultural economist, was appointed undersecretary of the same ministry, in addition to Canelli. In May 1937 Tassinari also took the responsibility for land reclamation and finally, at the end of October 1939, was appointed minister of agriculture.

At the beginning of his scientific training, in the early 1920s, Tassinari had been strongly influenced by Serpieri's teaching; after 1930-31, however, he started to criticize the model of land reclamation advocated by the latter, as, in his opinion, it relied too much on the goodwill of the landowners. Once in the government, he advocated instead a project of land reclamation focused on specific uncultivated areas in Southern Italy: these should have been expropriated by the State, provided with adequate infrastructure build by public agencies and transformed into small and medium size farms. In this period the new priority for Mussolini had become indeed the pursuit of national self sufficiency ('autarky') and then in 1939-40, this time overcoming the resistance of the local landowners, he gave his assent to an ambitious plan to expropriate and transform large properties in Sicily (Zaganella, 2010). At that time, however, Italy was sliding towards the war and this project could not be completed.

\section{The economists at the Chamber of Deputies}

As mentioned above, thanks to the Acerbo law and to systematic violence and intimidation, in 1924 the fascist party managed to gain a large majority in the Lower House. Several deputies, however, were elected in the ranks of the opposition parties. Among them, three were university professors in economics: Angelo Mauri, a catholic intellectual, Arturo Labriola, member of the socialist party and Antonio Graziadei, a co-founder in 1921 of the Italian communist party. As a result of the dramatic sequence of events that led in 1924-26 to the abolition of fundamental political rights and the establishment of an indisputed personal dictatorship by Mussolini,

${ }^{28}$ Giuseppe Tassinari (Perugia, 1891-Salò, 1944) taught agricultural economics at the Universities of Perugia and Bologna, where he became full professor in 1926, and forestry at the National Institute of Agricultural Economics in Florence, presided by Serpieri. From 1929 till 1939 was member of the Chamber of deputies and then, from 1939, of the Chamber of fasces and corporations. After September 1943, albeit critical of the fascist ruling élite, which he judged to be corrupt and incompetent, he adhered to the "Repubblica Sociale Italiana", the puppet State created by Mussolini with the help of the nazi regime and died in Salò in 1944 during an aerial attack (cf. Zaganella, 2010). In his academic writings Tassinari focused on the structural problems of the Italian agriculture, on the distribution of income among Italian farmers and on corporatism (Tassinari, 1931; 1933; 1937). 
their role in Parliament, however, was bound to be de facto ineffective. In the summer of 1924, after the kidnapping and killing by the fascists of the socialist leader Giacomo Matteotti, both Mauri and Labriola joined the strategy adopted by the socialist and centrist opposition to boycott parliamentary work until violence had ceased (so called "Aventine secession"). It is not surprising then that the parliamentary proceedings do not include in this period any speech by Mauri, whilst Labriola held only a minor speech, in April 1924, against an attempt by the majority to change the composition of the permanent commissions.

Graziadei, together with the communist party, did not join the boycott and continued his opposition from inside the Lower House, where he took the floor to attack the economic policy of the government. In a speech given in March 192529, in particular, he denounced the continuous increase in the cost of living in Italy, in a context in which wages had remained unchanged or had even decreased. This, he maintained, had resulted in a sharp deterioration in the standard of living of the workers. At the same time, Graziadei lamented the strong depreciation of the lira which had brought increases in the prices of imported goods and higher inflation. No less severe was his criticism of De' Stefani fiscal policy and government's decision to favour the bailout of a few credit institutions linked to the regime.

These sharp remarks, which identified several weak points of the fascist policy, were of course not welcomed by Mussolini. In October 1926, in the framework of a tightening of the dictatorship, all opposition members were expelled from the Chamber.

After this date, then, the remaining voices of the anti-fascist opposition were silenced. This does not mean, however, that the Chamber of deputies became simply an amplifier of the duce's will. Whilst from the second half of the 1930s conformism and even flattery became dominant, before this period the debate on the floor still reflected different positions within Fascism.

Among the deputies who, while adering to fascism, maintained a critical and nonconformist view, one of the most stimulating is undoubtedly the corporatist economist Agostino Lanzillo.

Lanzillo was a leading exponent of the "revolutionary syndicalism", a movement which maintained that factories should be owned and managed by the people who worked in them and which drew inspiration from the ideas of Georges Sorel ${ }^{30}$. After graduating in law at the University of Rome,

${ }^{29}$ A.P., Chamber, $11^{\text {th }}$ March 1925, 2439-45.

30 Lanzillo (Reggio Calabria, 1886-Milano, 1952) taught as assistant professor at the University "Bocconi" of Milan and at the University of Rome; in 1923 got the chair of political economy at the University of Cagliari. From 1934 was professor in the same discipline at University "Ca' Foscari", Venice. In his original and controversial writings 
he started a successful academic career as an economist but took also an active part to the political debate, becoming an outspoken critic of the socialist orthodoxy and advocating a synthesis between syndicalism and nationalism. In 1914-15 he actively campaigned in favour of Italy's participation to the war and then adhered very early to fascism, becoming a columnist of Popolo d'Italia, the official newspaper of the fascist movement. In 1924 was elected at the Chamber of deputies and the following year became a member of the so called "Commissione dei diciotto", a committee selected by Mussolini to shape Italy's political institutions according to the new regime (cf. De Felice, 1968, 42-46; Aquarone, 1965, 52 sgg). In this committee, he became supporter of a radical view of corporatism, seen as a system supporting the self-government of the productive categories. In his view, the corporations, not the government should take the key decisions in the spheres of production and distribution. This position, hostile to statism and centralization, brought to a gradual marginalization of Lanzillo inside the regime .

His speeches at Chamber of deputies, between 1924 and 1929, reflect his views of a 'leftist' fascist intellectual. On March 1925, commenting on the political situation 31 , he expressed strong criticism to the "Aventine secession". The events of the First world war demonstrated, maintained Lanzillo, that liberalism and democracy had failed: on that occasion the national interests had been defended not by the majority of population, who was against the war, but by a pugnacious minority, led by the fascists. This movement had therefore the right and indeed the duty to lead the country until his programme had been fulfilled. To this aim, violent means had been used in the past and would have to be used in the future; in Lanzillo's view, however, fascist violence was "ennobled by idealistic motivations" and led by a clear will to modernize the country 32 .

In another key speech, held in December 1925, Lanzillo commented critically the proposal, drafted by Alfredo Rocco, aimed at enacting a strict control by the government of both trade unions and employers' organizations ${ }^{33}$. According to this proposal, which anticipated the so called "Charter of Labour", only strictly fascist workers' and employers' organizations were entitled to draw 'collective' labour contracts, i.e. deals whose provisions were binding also for non unionized workers. To this aim, each area of activity could be legally represented only by a single, fascist, workers' and employers' organization, which had to apply for a formal recognition by the government and be submitted to continuous control.

(Lanzillo 1918; 1936; 1937) he focused on the crisis of liberalism and socialism and analysed the perspectives of capitalism after the Great depression.

${ }^{31}$ A.P., Chamber, 10th March 1925, 2392-6.

32 Ibidem, 2395.

33 A.P., Chamber, 5th Dec. 1925, 4849-55. 
Labour conflicts and the fixing of wages had to be dealt by special judiciary courts ('magistratura del lavoro'). Strikes and lockouts were forbidden and punished as a crime.

In his speech Lanzillo expressed support to the broad principles underlying the above mentioned proposal; as a matter of fact, however, he raised several critical observations. According to the syndicalist programme, indeed, Lanzillo wished that the newly organized unions would take a leading role in the production process and in policy decisions. As a consequence, he expressed reservations to government's control of everyday activity of the unions and opposed the view that the conflicting interests of workers and employers, including the determination of wages, should be entrusted to a specific labour judiciary. The very concept of 'fair wage', as well as that of fair price, he told the Chamber, was metaphysical. Struggle for income distribution and even strikes, provided they were not motivated by political reasons, were instrumental in fostering efficiency and productivity.

Given Lanzillo's heterodox views inside fascism and his independence of judgement, it is not surprising that in the following elections, scheduled in 1929, he was not included in the list of candidates to the Parliament (De Felice, 1968, 476). In the 1930s he became increasingly at odds with Mussolini's policies and focused on academic work at the University of Venice, writing several essays on corporatism and on the challenges facing capitalism after the great depression. Some of these were published on Critica Fascista, the journal edited by Giuseppe Bottai.

Another leading theorist of corporatism was Gino Arias, professor of political economy at the Universities of Genoa, Florence and Rome ${ }^{34}$. In 1924-25, similarly to Lanzillo, he was selected by Mussolini to take part to a key committee delegated to institutional reforms (Comitato dei diciotto): on that circumstance, he supported a moderate and more 'orthodox' view of the role of syndicates: to perform their functions, these should obtain indeed a formal recognition by the government; in each productive sector, however several syndicates had to compete to represent workers' interests. In the

34 Gino Arias was born in Florence in 1879 by a Jewish family. A prolific writer, he published between 1901 and 1906 several essays and monographs on the history of medieval economic and social institutions (cf. Arias, 1901; 1905). In the following years he focused on the analysis of economic institutions and phenomena in an historical perspective and in 1909 he got a chair of political economy at the University of Genoa, where he taught till 1924, when he moved to the University of Florence. During the 1920s, Arias adhered to fascism and wrote several essays on the theoretical foundations of corporatism (Arias, 1930) and on the 'Chart of labour', a key document elaborated in 1926 by Giuseppe Bottai. In 1936 he moved to the University of Rome to become professor of political economy at the faculty of law. On October 1938, after the enforcement by the regime of the racist laws against the Jews, he was forced to emigrate to Argentina, where he died shortly after his arrival, in the 1940. Cf. Ottonelli, 2012. 
following years he became a leading representative of the fascist economic and social doctrine: in this capacity he wrote regularly for Popolo d'Italia, the official newspaper of the fascist party and for Gerarchia, the journal founded by Mussolini and directed by Margherita Sarfatti (Ottonelli, 2012, 31 sgg).

Member of the Chamber of deputies since 1934, Arias took an activ part to the work of the committee on finance, where he drafted several internal documents. In the general assembly, however, he took the floor only on a few occasions, during the discussion of the budget of the ministry of corporations or as a speaker of the committee on finance. In March 1935, for example, he gave a speech to exalt the 'Chart of labour' which, he maintained, "transformed syndicates in the most powerful instrument of order and justice" and laid the foundation of corporatism ${ }^{35}$. Arias stressed the need for corporations to have their own research and documentation centres, in order to be able to analyse the problems of the sector they had to coordinate and to set new legislative and policy measures. The aim of the new corporative order, maintained Arias, was not to suppress private initiative, quite the contrary. Private firms, however, should 'spontaneously' conform to the new corporative 'spirit', modifying accordingly their methods of management, their relations with labour force and becoming conscious of their social duties. Interestingly, this point was met with perplexity and criticism by a few members of the Chamber: the parliamentary proceedings report "interruptions" and somehow ironic comments ${ }^{36}$.

In a speech held on March 1936 Arias provides a very optimistic view of the role and future developments of the corporative system ${ }^{37}$. The corporations, he maintains, would have "disciplined the entire national economy"38. They were "public institutions" whose role was to fulfil key regulating and law making functions under the coordination of the head of government. As public institutions, they should have sufficient personnel/civil servants. This bureaucratic apparatus, however, should have been reduced to a minimum so as not to deprive corporations of their flexibility. A partial exception to this framework was constituted, Arias acknowledged, by the steel and mechanical industries: given their importance for the national defence, these had to be placed under the

\footnotetext{
${ }^{35}$ A.P. , Chamber, $28^{\text {th }}$ March 1935, 1207-12.

${ }^{36}$ In his speech Arias mentioned the need to tackle the organization of new "corporate firms". To this point another deputy, Nazzareno Mezzetti, interrupted him: "a corporate firm? Could you explain what does it mean? Please, tell us" (A.P., 28 $8^{\text {th }}$ March 1935, 1209). Also an observation by Arias that the newly founded high schools aimed at forming the cadres of the fascist syndicates did not attract enough participants among workers' representatives was met with irony by the floor: "This is because the trade unionists have a better preparation than the teachers", a deputy observed (Ibidem, 1935).

${ }^{37}$ A.P. Chamber, $26^{\text {th }}$ March 1936, 2521-26.

${ }^{38}$ Ibidem, 2521.
} 
control of the State. Also in this case, however, Arias hoped for coordination with the the corporations ${ }^{39}$.

As we know, however, the organization of the Italian economy developed in a different direction from that desired by Arias and the corporatists: from the second half of the 1930s, Mussolini's priority became the transformation of the Italian economy into an instrument aimed at achieving objectives of military expansion and aggression. In this context, a centralized control of productive activity and of foreign trade was needed: corporatism, with his complex decision-making process could even become an obstacle. Arias anyway did not take part to this last phase of the fascist parable: at the end of 1938, following the adoption by the regime of the notorious racist laws, he was stripped, as a Jew, of all his institutional positions and expelled from the Parliament and from the University.

During the 1930s, as mentioned, critical debate inside the Chamber of deputies rarefied and conformism became increasingly dominant in deputies' speeches. A symptomatic case of this tendency is that of Gaetano Zingali, professor of statistics and public economics at the University of Catania and author of several essays on demography, on the Italian taxation system, on the measurement of wealth and income in Southern Italy 40.

Elected at the Chamber of deputies in 1929 and again in 1934, he gave several speeches in which he confirmed his role as an expert in applied statistics and national accounting but also his acritical support of the regime In December 1929, for example, he intervened during the general discussion on the budget of the Ministry of finance for the year 1927-28, a session which was attended also by Mussolini. This budget had been introduced to the general assembly by Gino Olivetti, speaker of the finance committee and also. In his speech Olivetti, who was secretary-general of the employers' association ('Confindustria') and therefore a leading representative of the industrialists' view, pointed out to two worrying phenomena which had negatively influenced during the previous year the Italian economy: an increase in fiscal pressure and a decrease of national income. This was indeed an implicit but substantial criticism to government's economic policy. Commenting on Olivetti's speech, Zingali denied that the increase in fiscal revenues, which had indeed happened, was the consequence of an heavier fiscal burden ${ }^{41}$. On the contrary, it had to be interpreted as the result of an enlargement of the taxing basis and a severe reduction of tax evasion.

39 In the same speech Arias denied that the national economic independence, advocated by Mussolini, could coincide with isolation: on the contrary, he maintained, international trade should continue to perform a crucial function (Ibidem, 2523).

${ }^{40}$ Cf. Zingali, 1924; 1925; 1933. Gaetano Zingali (Francofonte, 1894-Catania, 1975) taught statistics at the University of Catania since 1925 and became full professor of public economics at the same University in 1936.

41 A.P., Chamber, 5th Dec. 1925, 1387-89. 
The latter, he denounced quoting official data, had been widespread among the professionals, particularly in Southern Italy, till 1922-2342. Resolute action adopted by Fascist government, however, had curbed this phenomenon. In his speech, which was commented favourably by Mussolini, Zingali quoted also data on production to deny a widespread decrease of income ${ }^{43}$.

In another lengthy speech in which he combined professional use of available statistical data with flattery and adulation towards the regime, Zingali praised the public expenditure policy pursued by fascism, denying that this had brought to an increase of aggregate public expenditure and a worsening of the budget deficit: rather fascism had promoted a more efficient use of public resources with the aim to improve the welfare of the Italian people, in particular the poorest part of the population ${ }^{44}$.

Strong support for the regime, deriving however in this case by sincere ideological committment, was manifested also by Attilio da Empoli, professor of public finance and corporative economics at the Universities of Bari, Messina and Neaples ${ }^{45}$, member of the Chamber of deputies in the years 1934-39 and of the Chamber of fasces and corporations from 1939 till 1943.

In Parliament da Empoli intervened mainly on topics connected with public finance, advocating a moderate redistribution of income and measures aimed at reducing inequality and promoting "social justice" (Di Napoli, 2012) . In March 1935, for example, commenting the budget forecast of the ministry of education ${ }^{46}$, he suggested that school and university fees should be charged in proportion to household's income, rather than being fixed in amount. Fees, he observed, did not cover the entire cost of education and were integrated with resources deriving from taxation, including taxes

\footnotetext{
42 Ibidem, 1389-91.

${ }^{43}$ In December 1930 Zingali gave its support to a measure enacted by the government with the aim of reducing nominal wages of civil servants, arguing optimistically that this cut was more than compensated by the decrease of the prices of the goods consumed by workers together with a reduction of rents decided by the government. A.P., Chamber, $11^{\text {th }}$ Dec., 1930, 3656-62.

44 A.P., Chamber, 10th May 1932, 7034-55. After the second world war Zingali, in a compelling example of political opportunism, became a member of the liberal party and run for election in the democratic parliament, this time unsuccessfully.

${ }^{45}$ Attilio Da Empoli (Reggio Calabria, 1904-Napoli, 1948) was author of innovative essays in public finance. From 1929 till 1931, he completed his intellectual formation at the London School of Economics and then at Columbia University, Berkeley and Chicago. In 1936 he got a chair in public economics at the University of Bari; then taught at the Universities of Messina and Neaples. A committed nationalist and fascist, in 1935 he volunteered in the war in Ethiopia and, in 1941, in the campaign of Greece. In 1943, however, he distanced himself from fascism and in 1944 he enlisted in the reconstituted Italian army that fought alongside the Anglo-Americans. Cf. Faucci, 1985; Fusco, 2012. 46 A.P., Chamber, 6th March 1935, 856-64.
} 
on consumption, payed also by poor people who normally did not enrol in university. As a consequence, the education of the more affluent section of the society was subsidized, at least in part, by the less advantaged section.

More radical appears his proposal for a reform of the Italian tax system that he put forward in May 1935 during the discussion of the provisional budget of the Ministry of finance ${ }^{47}$. In this circumstance he suggested a system of progressive taxation based on the principle of equal marginal sacrifice. Tax rates, however, should not reach levels so high as to discourage savings.

Da Empoli took the floor also in December 1936, at the time of the approval of the government decree of October $5^{\text {th }}$ deliberating a substantial devaluation of the lira after a round of devaluations enacted by the monetary authorities of the major industrialized countries. In his speech ${ }^{48}$, Da Empoli placed the realignment of the lira within the framework of the monetary policy pursued by the regime since the stabilization process of 1926-27 ('quota novanta'). This latter measure, he maintained, had placed the Italian economy on a solid and non-inflationary footing and had made it possible to mitigate the adverse effect on real economy deriving from the deflationary pressures of the 1930s. However, the devaluations of the pound and the dollar, followed by realignments of most currencies, had made the search of a new equilibrium exchange rate of the lira unavoidable.

In May 1938, commenting on the floor the budget of the ministry of finance for 1938-39, he used enthusiastic tones: "what comes to your attention is the budget for the third year of Mussolini's empire: a Roman, fascist and corporate empire" 49 . In his speech da Empoli returned to the need to strenghten the progressiveness of the tax system in order to reduce income inequalities and to increase tax deductions to large families. His overall judgement, anyway, was very positive: the budget was inspired by the principles of sound finance that "had alone allowed the means necessary for the conquest of the empire". 50

After July 1943, the disastrous conduct of the war by Mussolini, a direct consequence of his totalitarian management of power, led da Empoli, who fought during the conflict as an army officer, to radically rethink his support for the regime and to become an active antifascist.

\footnotetext{
47 A.P., Chamber, 10th May 1932, 7034-55

${ }^{48}$ A.P., Chamber, $1^{\text {th }}$ Dec. 1936, 3111-3114.

${ }^{49}$ A.P., Chamber, 16th May 1938, 4963.

${ }^{50}$ Ibidem.
} 
5. Between residual autonomy and increasing regimentation: being an economist at the fascist Senate

Also the Senate, as mentioned, was submitted from the late 1920s to a process of fascistization. In this institution, however, the legacy of the prefascist past was stronger and the process of substituting the older, mainly liberal-oriented senators with politically more reliable new members was undoubtedly slower.

Among the representatives of the liberal prefascist élite, one of the most outstanding was Luigi Einaudi. Appointed to the Senate in 1919, Einaudi manifested his dissent by attending rarely to the sessions and avoiding from taking part in the discussions on the floor. Furthermore, in 1928 he voted against the new electoral law promoted by Alfredo Rocco and in 1935 to a Senate agendum in favour of Ethiopia's war (Faucci, 1986, 215).

Another influential economist, who came from a different approach but, as Einaudi, was alien to the fascist ideology, was Achille Loria, an eclectic thinker influenced by the German historical school (but also by Marx and Darwin) and author of original, albeit controversial, essays and monographs in which he tried to explain the economic and political evolution of societies on the basis of the abundance or scarcity of land51. Member of the Accademia dei Lincei since 1901, he was appointed to the Senate in October 1919.

In spite of the fact that, being alien to fascist ideology, he was subjected to increasing isolation, Loria took an active part in the work of the Senate. In March 1930, in a speech delivered in the presence of Mussolini during a debate on a law aimed at implementing the "National Council of Corporations", a new constitutional body, he expressed a favourable opinion on the role played by corporations on the economic and social system of Italy, as they could guarantee a continuous coordination between workers and employers ${ }^{52}$. In his analysis, Loria interpreted corporatism as a manifestation of the intervention of the State in the economy: as such, he

\footnotetext{
51 Achille Loria was born in Mantua to a Jewish family in 1857. After graduating in law at the University of Bologna, he continued his studies in Pavia, Berlin and London. In 1881 became professor political economy at the University of Siena and then moved to the Universities of Padua (1891) and Turin (1902), where he taught until his retirement in 1932. He died in November 1943 at Luserna San Giovanni, a mountain village not far from Turin. A prolific writer, Loria was acclaimed as an outstanding thinker during the 1880s and 1890s to be later subjected to harsh criticism by such authors as Benedetto Croce and Antonio Gramsci. Some of his works were translated in English and French and exerted a significant influence abroad. He was Italian correspondent of the Royal Economic Society and honorary fellow of the American Economic Association. Cf. Benson 1950; Faucci and Perri 2003.
}

52 A.P., Senate, $13^{\text {th }}$ March 1930, 1932. 
argued, this issue had been already raised by several XIX century economists, in particular the German Kathedersozialisten. In the same speech, however, Loria warned against the claims made by some supporters of corporatism that this would finally overcome the clash between social classes. The debate itself that had accompanied the approval of the same legislative proposal in the Chamber of deputies, observed Loria, had revealed that on crucial aspects the representatives of entrepreneurs and those of syndicates had different, even conflicting point of view ${ }^{53}$. To some extent, he added, these conflicts were indeed unaivodable and even beneficial.

In another remarkable speech, delivered in the Senate in May 1935, Loria focused on the Italian banking system, expressing a very positive evaluation of the legislative interventions that led to the establishment of the "Istituto per la Ricostruzione Industriale" (IRI) ${ }^{54}$. Thanks to these measures, stated Loria, it had been possible to overcome the main factors of instability affecting the major Italian banks, namely their tendency to invest short-term deposits in long-term loans. The problem was that, in many cases, orthodox short-term operations were insufficient to guarantee adequate profits to the banks, which could then be induced to engage in speculative operations. The optimal solution would have been to limit the number of banks by law, allowing the surviving banks to operate satisfactorily.

In the following three years, from 1935 to 1938, "physical and moral pains" 55 prevented Loria from taking part in the work of the Senate. In October 1938, then, he was struck, as a Jew, by the anti-Semitic legislation imposed by the regime. In an heartfelt letter to the President of the Senate, he recalled his profound patriotism, adding that he was confident that his family, which "had lived in Italy for centuries and had always given all its energy to the service of the country" would be exempted from persecution. As a matter of fact, Mussolini decided to 'discriminate', in other word to exempt from the most odious consequences of the anti-semitic legislation all senators of Jewish origin (Gentile, 2002, 88-89). However, this measure was not fully implemented and, anyway, the wound inflicted to him could hardly be healed: Loria retired to a small town near Turin where he died in November 1943.

The other two economists in Senate, Pietro Sitta and Federico Flora, whose intellectual formation was based on economic liberalism, on the

\footnotetext{
53 Ibidem, 1935-6. This statement caused an abrupt comment by Mussolini, who attended the session: "We never ruled out these [contrasts]", he told the Senators, briefly interrupting Loria.

${ }^{54}$ A.P. Senate, $28^{\text {th }}$ May $1935,1317-21$.

55 Senate archives, Letter of Achille Loria to the President of the Senate, 31th Oct. 1938.
} 
contrary, during the 1920s adhered to fascism and put their intellectual skills at the service of the regime, by playing an important role as experts.

Pietro Sitta ${ }^{56}$ was an agricultural economist, author of renowned essays and monographs on land and agricultural credit and on taxation of landed property. From the first decade of the twentieth century, he accompanied this work as scholar with an intense activity in Parliament and at the government: he joined the Chamber of deputies in 1915 and was reelected in the following two legislatures until 1924, when he was appointed Senator. In 1919 he held government positions as undersecretary at the ministry of agriculture and then at the ministry of industry and trade. In the postwar period then, he approached Mussolini's regime and in May 1925 became part of the fascist party.

In Senate Sitta took an active part in the discussion and was member of several committees. In May 1930 he took the floor during the discussion of the budget of the Ministry of Corporations to address issues relating to social security and social assistance which, he recalled, had passed under the jurisdiction of that ministry. In his speech, Sitta took the opportunity to praise the results achieved by fascism in this field but wondered whether the ministry had sufficient resources to cope with the new tasks, with particular reference to the inspection and supervision of public and public institutions under its jurisdiction ${ }^{57}$.

In March 1931 he intervened on the problem of agricultural credit, a few years after the approval of a comprehensive bill 58 that had benefited from "appropriate observations of the Senate"59. According to Sitta, this law had considerably improved the conditions for granting credit to the farmers. However, there was room for further improvement, especially to avoid the danger of over-indebtedness in the sector and to control interest rates and the high costs of expertise charged by some credit institutions ${ }^{60}$.

Federico Flora, professor at the University of Bologna from 1910 till 193761, was an highly reputed expert of public services management, public

\footnotetext{
56 Pietro Sitta (Ferrara, 1866 - Ivi, 1947) graduated at High School of Commerce "Ca' Foscari" of Venice. In 1902 became full professor of political economy at the University of Ferrara where he taught until retirement and where he held the position of rector for several years. He wrote several essays and monographs on agricultural economics (cf. Sitta, 1895; 1933). He was member of the National Institute of Statistics (ISTAT) and corresponding member of "Accademia dei Georgofili". Cf. Morselli, 1948.

57 A.P., Senate, $26^{\text {th }}$ May 1930, 2598-2602.

58 Law $29^{\text {th }}$ July 1928, no. 2085.

59 A.P. Senate, $25^{\text {th }}$ March 1931, 3523.

60 Ibidem, 3523-3525.

61 Federico Flora (Pordenone, 1867 - Chiusi, 1958) was professor of public finance at the University of Catania (since 1904) and Bologna, where he taught until 1937. His academic writings include an influential handbook of public finance (Manuale di Scienza delle Finanze, first edition 1893) and several essays on public debt management, pauperism,
} 
debt and exchange rates policies. As mentioned, he had a liberal background (he drew inspiration from Francesco Ferrara and other Italian liberal thinkers). From the second half of the 1920s, however, he gradually approached Mussolini's regime: in December 1929 he became a member of the "National association of fascist university professors" and in July 1933 he joined the fascist party. This undoubtedly facilitated his appointment as Senator, which took place in February 1934.

In Senate he carried out an intense activity, as a speaker and commentator of several legislative proposals . From 1939 till 1943 he took part in the work of the Committee on Finance.

In May 1935 he spoke on the budget of State railways62, a subject, he warned, that deserved the utmost attention not only for the size of this account but also for the serious repercussions it had on the Treasury, which by law appropriated the surpluses but also assumed the operating deficits of the sector. Now, until the end of the 1920s the railways administration realized a surplus. With the depression, in the early 1930s, the volume of traffic had fallen by more than a third. This had resulted in a deficit of 900 million lira in the year 1935-36, half of the total of the public sector deficit, and had caused widespread concern among public opinion which was increasingly considering railways as a burden. This point of view however, maintained Flora, was utterly unfair: if an overall calculation would have been made of the costs and benefits stemming from the railways, the result would have been hugely positive.

In December Flora intervened on the decree adopted by the government on $5^{\text {th }}$ October to devalue the lira. In his speech Flora maintained that, following the recent devaluation of the French franc and of the leading international currencies, this measure was inevitable: "monetary nationalism in a world economy like ours is not a sustainable decision: monetary problems do not allow purely national solutions"63. It was crucial, however, to keep the domestic price dynamics under control, in order to avoid significant increases that would have twarted the positive effects of the devaluation on the trade balance and would have resulted in adverse redistributive effects on fixed income earners.

rail transport tariffs and currency policy (Cf. Flora, 1896; 1907; 1909; 1930). He was member of the Royal Academy of Science of Bologna and of the "Accademia dei Lincei" of Rome and took part as a delegate of the Italian government in the Dawes committee. Flora was also an active commentator of economic facts and policies on national based newspapers. Cf. Colonna, 1987.

62 A.P. Senate, 17 th May 1935, 1193-1200.

63 A.P. Senate, 22th Dec. 1936, 2555. 


\section{Concluding remarks}

It is now possible to take up the main issues that emerged in this paper with the aim of outlining some interpretative lines. A first important point to bear in mind, particularly for the purpose of a comparison with the work done by the economists in the Italian Parliament during the 'liberal age', is that the fascist regime enacted a deep shift in the balance of power between the legislative and the executive. The Chamber of deputies, in particular, lost the centrality and the representativeness it had during the 'liberal age': after 1929, when a new electoral law was enforced, its members were selected directly by the 'Grand council of fascism' from a list of candidates chosen by the corporative confederations, a few national associations and academic institutions. The evolution of the Senate was different: from the 1930s, however, also this institution became increasingly 'fascistized'.

From the end of the 1920's, therefore, no anti-fascist opposition was tolerated in Parliament. This does not mean, however, that this institution became simply a 'rubber stamp' for the bills drafted by the government. An interesting aspect which stems from a systematic analysis of the parliamentary proceedings, is that the debate on the floor still reflected different positions within the fascist regime, connected mainly to different interest groups (the representatives of the employers' organizations and of the fascist trade unions, the landowners, the representatives of the professional associations).

The internal structure of the executive power also changed substantially: a dominant role was assumed by Mussolini who enforced his personal dictatorship and entrusted the ministries on economic and financial issues mainly to experts, whose role was to implement policy decisions ultimately taken by the duce himself.

In this context, it is hardly surprising that the vast majority of the economists who acted as legislators and policymakers during Mussolini's regime supported more or less wholeheartedly the fascist ideology. At the Chamber of deputies the only exception was constituted by three professors of economics elected in 1924 among the ranks of the opposition (Angelo Mauri, Arturo Labriola and Antonio Graziadei). In October 1926, however, all members of the opposition were expelled by the Chamber and their voice was silenced. In the Senate a dissenting position was held by Luigi Einaudi, an outstanding representative of the economic and political liberalism and by Achille Loria, an eclectic thinker influenced by the German historical school and to some extent, by marxism. Whilst Einaudi manifested his dissent by avoiding taking part to the debates on the floor, Loria held a few authoritative speeches to discuss from a purely 'technical' point of view key initiatives taken by the government . 
Another point highlightened by this research is that most of the economists in Parliament or at the government during these years were professors in applied economics. In particular, it is worth to underline the presence of a substantial group of agricultural economists: six in total, three of whom, respectively Arrigo Serpieri, Giacomo Acerbo and Giuseppe Tassinari became ministries or undersecretary of agriculture and, at the same time, were members of the Chamber of deputies; two, Vincenzo Ricchioni and Zeno Vignati were only members of this Chamber; one, Pietro Sitta, was a senator. This confirms the crucial role attributed to agriculture by the regime, at an economic and, perhaps even more, political and social level.

A key role was also played by scholars in public economics and finance: in primis Alberto De' Stefani, minister of finance in the years 1922-25; but also Gaetano Zingali and Attilio da Empoli, members of the Chamber of deputies, and Federico Flora, member of the Senate. The role of the theorists of corporatism was significant but circumscribed: this paper analyses the activity of Agostino Lanzillo and Gino Arias.

There is another aspect that, in our view, can be drawn from this research and allows us to provide new insight not only on the role of the economists in these years but also on the intrinsic shortcomings of Mussolini's dictatorship. As mentioned before, several of the economists who played a key role in building the fascist State were among the most valuable experts in their respective fields, beside being strongly committed to fascist and corporatist ideology. Mussolini, however, did not hesitate to put them aside whenever his strategic priorities changed or fundamental political issues emerged. This was the case of De' Stefani, whose measures against stock market speculation made him unpopular among influential financial circles and whose orthodox customs policy was hardly compatible with Mussolini's aim of stabilizing the lira at an high exchange rate; it is also the case of Serpieri, whose policy of "bonifica integrale" risked to alienate many landowners from the regime and, anyway, absorbed substantial public resources which Mussolini needed for his new priority, the Ethiopian war.

All of this pales in the face of the tragedy of the racist laws, strongly supported by Mussoliny and approved in October 1938; laws that destroyed the careers and put at risk the lives of so many intellectuals of Jewish descent, no matter if they had been alien to fascism (this was the case of Achille Loria) or, as in the case of Gino Arias, had actively contributed in the previous years to build the foundations of that ideology. 


\section{BIBLIOGRAPHY}

Aquarone, A. (1965), L'organizzazione dello Stato totalitario, Torino, Einaudi. Arias, G. (1901), Storia e documenti di storia del diritto, Firenze, Le Monnier.

Arias, G. (1905), Il sistema della costituzione economica e sociale italiana nell'età dei Comuni, Roma-Torino.

Arias, G. (1930), Economia politica e politica economica corporativa, Firenze, Poligrafica Universitaria.

Augello, M.M. - M.E.L. Guidi (Eds.) (2002), Una storia dell'economia politica dell'Italia liberale. 1. La scienza economica in Parlamento 1861-1922, Milano, FrancoAngeli.

Augello, M.M. - M.E.L. Guidi (Eds.) (2003), Una storia dell'economia politica dell'Italia liberale. 2. Gli economisti in Parlamento 1861-1922, Milano, FrancoAngeli.

Augello, M.M. - M.E.L. Guidi (Eds.) (2005), Economists in Parliament in the Liberal Age (1848-1920), Burlington, Ashgate.

Barucci, P. -S. Misiani - M. Mosca (2017), La cultura economica italiana (18891943), Milano, FrancoAngeli.

Benson L. (1950), "Achille Loria's Influence on American Economic Thought", Agricultural History, 24, 4 (October), 182-199.

Clough S.B. (1964), The Economic History of Modern Italy, New York, Columbia University Press.

Colonna, M. (1987) "Flora, Federico", in Dizionario Biografico degli Italiani [hence $D B I$, v. 48, Roma, Ist.Enc.It., 306-8.

Daneo, C. (1980), Breve storia dell'economia italiana, 1860-1970, Milano, Mondadori.

De Felice, R. (1968), Mussolini il fascista. II. L'organizzazione dello Stato fascista 1925-1929, Torino, Einaudi.

De' Stefani, A. (1926), La restaurazione finanziaria 1922-1925, Bologna, Zanichelli.

Di Napoli, M. (2012), "Un economista a Montecitorio nel periodo fascista”, in M. Di Matteo-E. Longobardi (eds.), Attilio da Empoli (1904-1948). Un economista partecipe del suo tempo, Milano, FrancoAngeli, 217-28.

Dini, M. (2010), "Introduzione", in A. Serpieri, Memorie per il futuro, Firenze, Le Monnier, 1-63.

Faucci, R. (1985), "Da Empoli, Attilio", in DBI, v. 31, Roma, Ist.Enc.It., 361-5.

Faucci, R. (2014), A History of Italian Economic Thought, London, Routledge.

Faucci R., Perri S. (2003), "Achille Loria: His Vision and Economic Analysis”, in W.J. Samuels (ed.), European Economists of the Early Twentieth Century, vol. 2, Elgar, Cheltenham, 203-238.

Fimiani, E. (2001), "Fascismo e regime tra meccanismi statutari e Costituzione materiale (1922-1943)", in M. Palla (Ed.), Lo Stato fascista, Milano, Nuova Italia, pp. 79-176.

Flora, F. (1893), Manuale di scienza delle finanze, Livorno, Giusti.

Flora, F. (1896), La questione sociale, Torino, Roux.

Flora, F. (1907), La politica delle tariffe ferroviarie, Catania, Giannotti. 
Flora, F. (1909), Ferrovie e finanze in Italia, Torino, STEN.

Flora, F. (1930), La liquidazione finanziaria della guerra: i piani Dawes e Young, Padova, CEDAM.

Fusco, A.M. (2012), "Attilio da Empoli: spunti per una biografia”, in M. Di Matteo-E. Longobardi (eds.), Attilio da Empoli (1904-1948). Un economista partecipe del suo tempo, Milano, FrancoAngeli, 27-77.

Gentile, E. (2002), Il totalitarismo alla conquista della Camera alta, Rubbettino, Soveria Mannelli.

Gentile, E. - Campochiaro E. (eds.) (2003), Repertorio biografico dei Senatori dell'Italia fascista, Napoli, Bibliopolis.

Guarneri, F. (1986), Battaglie economiche tra le due guerre, Bologna Il Mulino

Lanzillo, A. (1918), La disfatta del socialismo: critica della guerra e del socialismo, Firenze, Libr. della Voce.

Lanzillo, A. (1936), Lo Stato nel processo economico, Padova, CEDAM

Lanzillo, A. (1937), Lezioni di economia corporativa, Padova, CEDAM.

Loria, A. (1886), La teoria economica della costituzione politica, Torino, Bocca. English transl.: The Economic Foundations of Society, London, Swan, 1899.

Marchionatti, R. (ed.) (2000), "From our Italian correspondent". Luigi Einaudi's articles in The Economist, 1908-1946, Vol. II, Firenze, Olschki.

Marcoaldi F. (1986), Vent'anni di economia e politica. Le carte di De' Stefani (19221941), Milano, Franco Angeli.

Marcoaldi, F. (1991), "De' Stefani, Alberto”, in DBI, v. 39, 429-36

Melis, G. (2018), La macchina imperfetta. Immagine e realtà dello Stato fascista, Bologna, Il Mulino.

Misiani, S. (2018), "Serpieri, Arrigo", DBI, v. 92, Roma, Ist.Enc.Ital., 172-9.

Morselli, E. (1948), Pietro Sitta e le sue opere economiche, Ferrara, S.A.I.G.

Ottonelli, 0. (2012), Gino Arias (1879-1940). Dalla storia delle istituzioni al corporativismo fascista, Firenze, Firenze University Press.

Parisella, A. (1988), “Acerbo, Giacomo”, DBI, v. 34, Roma, Ist.Enc.Ital., 10-14.

Salvemini, G. (1936), Under the Axe of Fascism, London, Gollancz.

Salvemini, G. (1937), "Totalitarian 'Elections' in Italy Today”, Social Research, v. 4, no. 1, Feb., pp. 108-23

Serpieri, A. (1930), La guerra e le classi rurali italiane, Bari, Laterza; New Haven, Yale Univ Press.

Serpieri, A. (1931), La legge sulla bonifica integrale nel primo anno di applicazione, Roma, Ist.Pol. dello Stato.

Serpieri, A. (1933), La legge sulla bonifica integrale nel terzo anno di applicazione, Roma, Ist.Pol. dello Stato.

Serpieri, A. (1935), "The National Institute of Agricultural Economics in Italy", Journal of Farm Economics, vol. 17, 4, 646-58.

Serpieri, A. (1957), La bonifica nella storia e nella dottrina, Bologna, Edizioni agricole.

Sitta, P. (1895), Le finanze estensi. Saggio di storia economica, Ferrara, Tip. Sociale.

Sitta, P. (1933) Credito agrario e credito fondiario in Italia, Bologna, Zanichelli.

Soddu, F. (2008), "Il Parlamento fascista", in Lo Stato negli anni Trenta: istituzioni e regimi fascisti in Europa, a cura di G. Melis, Bologna, Il Mulino. 
Tassinari, G. (1931), La distribuzione del reddito nell'agricoltura italiana, Piacenza, Fed. It. Consorzi Agrari.

Tassinari, G. (1933), Problemi dell'agricoltura italiana, Roma, Conf. naz. fascista agricoltori.

Tassinari, G. (1937), Scritti di economia corporativa, Bologna, Zanichelli.

Tassinari, G. (2019), Diari. Il fascista che disse di no a Hitler, Milano, Luni.

Tattara, G. (1973), "Cerealicoltura e politica agraria durante il fascismo", in G. Toniolo (ed.), Lo sviluppo economico italiano, 1861-1940, Bari, Laterza, 373404.

Zaganella, M. (2010), Dal fascismo alla DC. Tassinari, Medici e la bonifica nell'Italia tra gli anni Trenta e Cinquanta, Siena, Cantagalli.

Zaganella, M. (2015), "La nascita dell'economia politica agraria e la cultura economica del Mezzogiorno", in P. Barucci, S. Misiani, M. Mosca, (eds), La cultura economica tra le due guerre, Milano: FrancoAngeli.

Zamagni V. (1993), The Economic History of Italy. 1860-1990, Oxford, Clarendon Press.

Zingali, G. (1924), Sull'ammontare della ricchezza privata in Sicilia, Città di Castello. Zingali, G. (1925), La bilancia alimentare prebellica e postbellica di alcuni Stati di Europa , Città di Castello,

Zingali, G. (1933), Liberalismo e fascismo nel Mezzogiorno d'Italia, Milano, Treves. 